Short communication

\title{
Occurrence of Ipomoea tenuipes Verdc., (Convolvulaceae) in Khandesh region Maharashtra, India
}

\author{
Revan Y. Chaudhari ${ }^{1}$ and Tanveer A. Khan ${ }^{2 *}$ \\ ${ }^{1}$ Department of Botany, M. J. College Jalgaon, Maharashtra, India \\ ${ }^{2}$ Department of Botany, H. J. Thim College of Arts and Science, Mehrun, Jalgaon, Maharashtra, India \\ *Corresponding Author: tanveerkhan04@gmail.com \\ [Accepted: 07 August 2020]
}

[Cite as: Chaudhari RY \& Khan TA (2020) Occurrence of Ipomoea tenuipes Verdc., (Convolvulaceae) in Khandesh region Maharashtra, India. Tropical Plant Research 7(2): 403-405]

\section{INTRODUCTION}

The vegetation of Khandesh region is quite varied and interesting and divided into three districts Jalgaon, Dhule and Nandurbar. It lies at the Northwestern corner of the Deccan plateau, in the valley of the Tapti river, and is bound to the north by the Satpuda ranges, to the east by the Berar (Vidarbha) region, to the south by the hills of Ajanta, belonging to the Marathwada region of Maharashtra, and to the west by the Northern most ranges of the Western Ghats, and beyond that the coastal plain of Gujarat. Khandesh region lies between $20^{\circ} 8^{\prime}$ and $22^{\prime} 7^{\prime}$ North latitude and $73^{\circ} 42^{\prime}$ and $76^{\circ} 28^{\prime}$ East longitude. The forest of the Khandesh region is of dry deciduous type. Khandesh region though botanically rich in biodiversity have not been explored extensively except a few sporadic reports on floristic of Yadav et al. (2003), Patil (2003), Valvi et al. (2006), Kshirsagar \& Patil (2008), Khan et al. (2015) and Khan (2019).

In the family Convolvulaceae Ipomoea $\mathrm{L}$. is also dominant genera. Ipomoea L. denoted by about 650 species, mostly confined to the tropical and warm temperate regions of the world (Mabberley 2008). Santapau \& Henry (1973) informed ca. 60 species for India. Afterwards Ipomoea mombassana Vatke (Biju et al. 1998); Ipomoea parasitica (Kunth) G.Don (Biju 2002) and Ipomoea ochracea (Lindl.) G. Don (Shimpale et al. 2012) have been additional to Indian flora, taking the total number of Ipomoea L. increase into 63 species for India.

While exploring the Khandesh region of the state of Maharashtra, the authors came across an interesting species of Ipomoea tenuipes Verdc. from Jalgaon district, Maharashtra. Which is a native of Africa and first time recollected after a gap of 53 years from Maharashtra in India (Shimpale et al. 2014). During present investigation Ipomoea tenuipes Verdc. is a second distributional records for India.

Through search of literature (Singh et al. 2001, Patil 2003, Kshirsagar \& Patil 2008, Khan 2019) and consultation of BSI Herbarium Pune revealed that this species was not reported from Khandesh region in Maharashtra. This species is rare to Indian flora because it was collected from one locality of Maharashtra State and the present collection adds second locality in India. The voucher specimens are deposited in the herbarium of Department of Botany, H. J. Thim College of Arts and Science Mehrun, Jalgaon. Therefore, Ipomoea tenuipes Verdc., is reported here for the first time from Satpuda range of Khandesh region of Maharashtra State. Detailed description and notes are provided here to facilitate easy identification.

\section{ENUMERATION}

Ipomoea tenuipes Verdc., Kew Bull. 15: 12. 1961; Shimpale et al. in Rheedea 24: 117.2014.

[Fig. 1]

Convolvulus heptaphyllus Rottl. \& Willd. in Neue Schriften Ges. Naturf. Freunde Berlin. 4: 196. 1803.

Annual herbs. Stems twining or sometimes prostrate, slender, glabrous. Lamina palmately divided at base, 9-10 $\times 8-9 \mathrm{~cm}$; lobes elliptic to lanceolate $2.5-4.5 \times 0.5-1.0 \mathrm{~cm}$, typically obtuse and sometime apiculate at apex, at base narrowed and sub-petioluled, outer ones 2-lobed; petiole glabrous, $4.5-5.5 \mathrm{~cm}$ long; pseudostipules glabrous, existing like the leaves but much smaller. Flowers solitary or 2-3 flowered cymes, axillary; peduncle almost filiform, slender, 5.5-6.5 cm long, glabrous; pedicels slender $1.5-1.8 \mathrm{~cm}$ long, slightly sub-clavate; bracteoles minute, middle of the pedicel. Sepals orbicular or elliptic, $3.5-4.5 \times 3.5-5.5 \mathrm{~mm}$, sub-equal with membranous edges, typically obtuse but mucronulate, sometime muriculate. Corolla funnel-shaped, rose-purple 
or dark mauve, 0.6-1.8 $\times 0.5-1.5 \mathrm{~cm}$, with narrow apiculate lobes. Stamens 5, unequal in length, included, adnate to corolla lobe. Capsules globose, brown, glabrous, 6.5-7.5 × 7.5-8.5 mm, 4-valved. Seeds 2-4, subglobose, brown, 3.5-4.5 × 2.5-3.0 mm, velvety pubescent, 6-10 $\mathrm{mm}$ long white cottony hairs at surface.

Flowering and Fruiting: October-January.
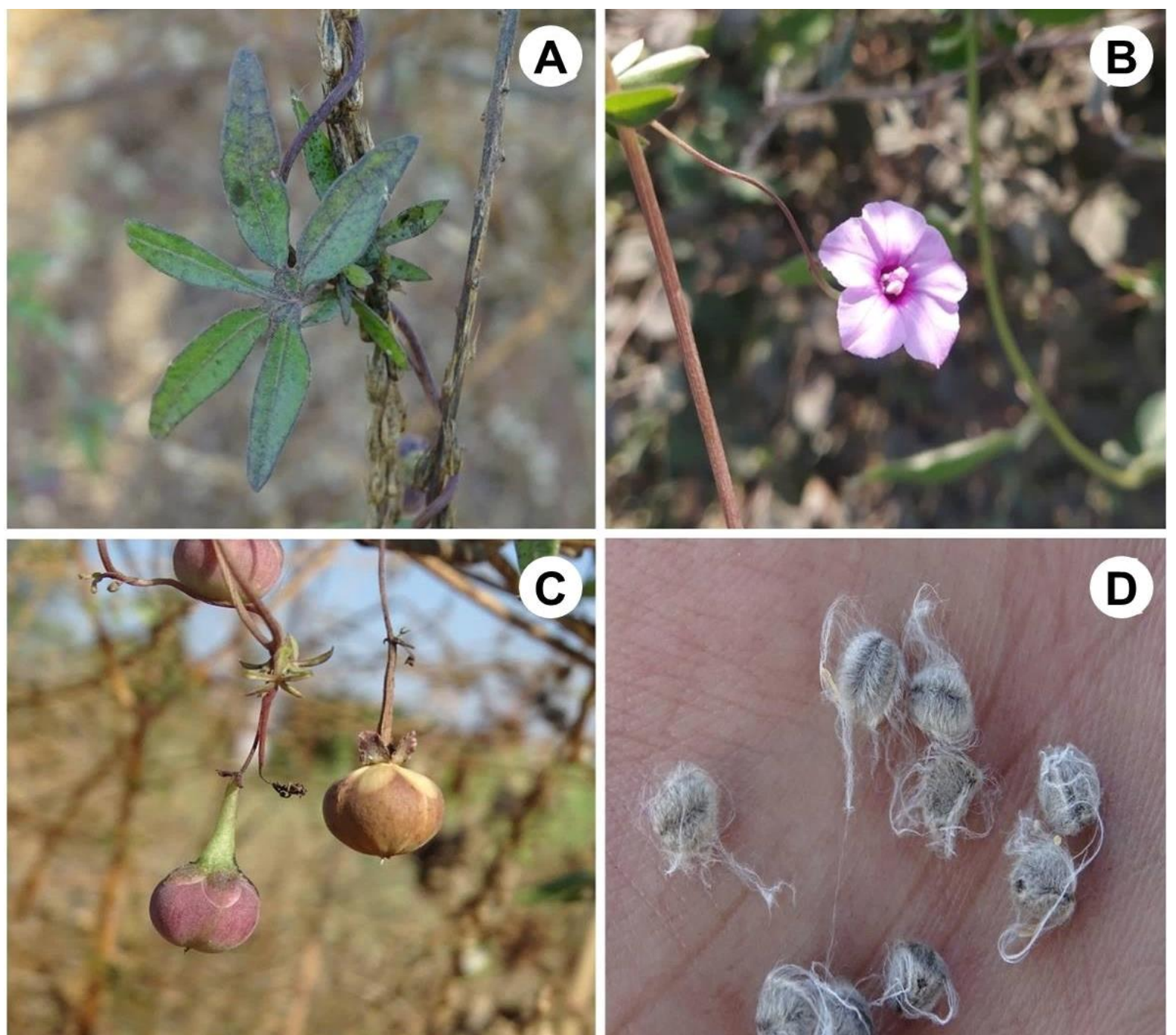

Figure 1. Ipomoea tenuipes Verdc.: A, Leaf; B, Flower; C, Fruits; D, Seeds.

GPS Reading: N $21^{\circ} 6^{\prime} 33.08^{\prime \prime}$, E 75³2' 16.63"' (Elevation $237.6 \mathrm{~m}$ )

Habitat: Rare. It mostly twining herb, growing over shrubs or herbs along the road sides, usually in black cottony or loamy soil.

Distribution: In India only reported from Paithan.

Specimens examined: INDIA, Maharashtra, Jalgaon District: 13.10.2019, TAK 7419 (CAL); Kanarda, 24.11.2019, TAK 7538 (CAL); Vidgaon, along the road sides in agricultural field, 05.01.2020, TAK 8193 (CAL); growing over shrubs along the road sides of Devjiri forest.

Note: Look similar to Ipomoea cairica (L.) Sweet. but It can be identify by its annual herb, lamina palmately divided at base, Sepals orbicular. Corolla funnel-shaped, rose-purple with narrow apiculate lobes. Capsules globose, brown. Seeds sub-globose, brown with white cottony hairs at surface.

\section{ACKNOWLEDGEMENTS}

The authors wish to express their gratitude to Dr. Vinod Shimpale Department of Botany, The New College, Kolhapur, for confirming the identity of the species. Thanks are also due to the Principal, H. J. Thim College, Jalgaon, for providing laboratory and library facilities.

\section{REFERENCES}

Biju SD, Matthew P \& Kumar VM (1998) Ipomoea mombassana Vatke (Convolvulaceae) - A new record for 
India. Journal of Economic and Taxonomic Botany 22(2): 471-473.

Biju SD (2002) Ipomoea parasitica (Kunth) G. Don (Convolvulaceae): A new record for India. Rheedea 12(1): 77-79.

Khan TA, Desai VV \& Gawande NR (2015) Four New Flowering plant Records from Satpuda Range of Jalgaon District, (MS) India. Bioscience Discovery 6(1): 45-48.

Khan TA (2019) Wild Flowers of Jalgaon District A succinct field guide. Prashant publication Jalgaon, pp. 2332.

Kshirsagar SR \& Patil DA (2008) Flora of Jalgaon District, Maharashtra. Bishen Singh Mahendra Pal Singh, Dehradun, India, pp. 219-224.

Mabberley DJ (2008) The Plant Book: A portable dictionary of plants, their distribution and uses, $3^{\text {rd }}$ Edition. Cambridge University Press, Cambridge, UK.

Patil DA (2003) Flora of Dhule and Nadurbar District, Maharashtra, Bishan Singh Mahendra Pal Singh Deharadun, pp. 399-408.

Santapau H \& Henry AN (1973) A dictionary of the flowering plants in India. CSIR, New Delhi, pp. 83.

Shimpale VB, Kshirsagar PR \& Pawar NV (2012) Ipomoea ochracea (Convolvulaceae) - A new record for India. Rheedea 22(2): 99-102.

Shimpale VB, Kare MA, Londhe DK \& Bhuktar AS (2014) On the occurrence of Ipomoea tenuipes (Convolvulaceae) in India. Rheedea 24 (2): 117-119.

Singh NP, Lakshminarasimhan P, Karthikeyan S \& Prasanna P (2001) Flora of Maharashtra State. Dicotyledones, Vol. II. Botanical Survey of India, Calcutta, pp. 454-473.

Valvi RJ, Yadav SS \& Varghese M (2006) New record of orchid species for the flora of West Khandesh Satpuda. Plant Archives 6(2): 753-755.

Yadav SS, Patil VS \& Mathew V (2003) Seven new flowering plant records from Khandesh Satpuda, Maharashtra State. Plant Archives 3(1): 129-131. 